\title{
TISSUE-SPECIFIC BIOCONCENTRATION AND BIOTRANSFORMATION OF CYPERMETHRIN AND CHLORPYRIFOS IN A NATIVE FISH (JENYNSIA MULTIDENTATA) EXPOSED TO THESE INSECTICIDES SINGLY AND IN MIXTURES
}

\author{
Rocío Inés Bonansea, $\dagger \ddagger$ Damián J.G. Marino,§ Lidwina Bertrand, $\dagger \ddagger$ Daniel A. Wunderlin, $\dagger \|$ \\ and María Valeria AmÉ*†‡ \\ $\dagger$ Facultad de Ciencias Químicas, Universidad Nacional de Córdoba, Córdoba, Argentina \\ †Centro de Investigaciones en Bioquímica e Inmunología, CONICET, Córdoba, Argentina \\ $\S$ Centro de Investigaciones del Medio Ambiente, Facultad de Ciencias Exactas, Universidad Nacional de La Plata, La Plata, Argentina \\ |Instituto de Ciencia y Tecnología de Alimentos Córdoba, CONICET, Córdoba, Argentina
}

(Submitted 29 February 2016; Returned for Revision 9 May 2016; Accepted 3 September 2016)

\begin{abstract}
The aim of the present study was to evaluate the accumulation of cypermethrin and chlorpyrifos when the fish Jenynsia multidentata was exposed to these pesticides singly and in technical and commercial mixtures. Adult female fish were exposed over $96 \mathrm{~h}$ to $0.04 \mu \mathrm{g} / \mathrm{L}$ of cypermethrin; $0.4 \mu \mathrm{g} / \mathrm{L}$ of chlorpyrifos; $0.04 \mu \mathrm{g} / \mathrm{L}$ of cypermethrin $+0.4 \mu \mathrm{g} / \mathrm{L}$ of chlorpyrifos in a technical mixture; and $0.04 \mu \mathrm{g} / \mathrm{L}$ of cypermethrin $+0.4 \mu \mathrm{g} / \mathrm{L}$ of chlorpyrifos in a mixture of commercial products. Fish exposed to cypermethrin accumulated this compound only in muscle, probably because of the low biotransformation capacity of this organ and the induction of cytochrome P4501A1 (CYP1A1) expression in the liver. The accumulation of chlorpyrifos occurred in fish exposed to the insecticide (intestine $>$ liver $>$ gills) even when these fish had higher gluthatione-S-transferase (GST) activity in gills and P-glycoprotein $(P$-gp $)$ expression in the liver, compared with the control. Fish exposed to the technical mixture showed cypermethrin accumulation (liver $>$ intestine $>$ gills) with higher levels than those measured in fish after only cypermethrin exposure. Higher expression levels of $C Y P 1 A 1$ in the liver were also observed compared with the Control. Fish exposed to the commercial mixture accumulated both insecticides (cypermethrin: intestine $>$ gills and chlorpyrifos: liver $>$ intestine $>$ gills $>$ muscle). In the organs where accumulation occurred, biotransformation enzymes were inhibited. Consequently, the commercial formulation exposure provoked the highest accumulation of cypermethrin and chlorpyrifos in J. multidentata, possibly associated with the biotransformation system inhibition. Environ Toxicol Chem 2017;36:1764-1774. (C) 2016 SETAC
\end{abstract}

Keywords: Tissue distribution Metabolism Mixtures Gas chromatography electron capture detector High-performance liquid chromatography electrospray ionization source quadrupole time-of-flight analyzer

\section{INTRODUCTION}

Chlorpyrifos and cypermethrin concentrations were reported together in aquatic environments worldwide during the last $15 \mathrm{yr}$ [1-4]. In Argentinean basins, the concentrations of these pesticides can range from less than $0.2 \mathrm{ng} / \mathrm{L}$ to $3.5 \mu \mathrm{g} / \mathrm{L}$ for cypermethrin and $0.2 \mathrm{ng} / \mathrm{L}$ to $17 \mu \mathrm{g} / \mathrm{L}$ for chlorpyrifos [4-7]. Cypermethrin and chlorpyrifos belong to pyrethroids and organophosphorus pesticides, respectively, and such a combination is common in pesticide applications both in households and in agricultural activities [8].

Mixed pesticides, compared with single pesticides, could cause significant synergistic effects of toxicity on target species, although they are also effective on nonpest species such as invertebrate or fish. Denton et al. [9] reported synergistic effects when mixtures of diazinon (organophosphorus insecticide) and esfenvalerate (pyrethroid insecticide) were tested using fish larvae fathead minnows (Pimephales promelas). Atrazine (herbicide of the triazine class) exposures in mixtures with chlorpyrifos significantly increase the inhibition of cholinesterase enzyme activity and chlorpyrifos-uptake kinetics in Xenopus laevis and $P$. promelas [10]. However, mixtures of carbofuran (carbamate insecticide) and methamidophos (organophosphorus

\footnotetext{
* Address correspondence to vame@ fcq.unc.edu.ar

Published online 7 September 2016 in Wiley Online Library

(wileyonlinelibrary.com).

DOI: $10.1002 /$ etc.3613
}

insecticide) exhibit a synergic or partial additive in the median lethal concentration values (LC50) after $96 \mathrm{~h}$ of exposure on trout larvae Oncorhynchus mykiss [11]. In addition, Brodeur et al. [12] observed synergistic effects in the value of LC50 in tadpoles (Rhinella arenarum) exposed to mixtures of glyphosate and cypermethrin for $96 \mathrm{~h}$. Nevertheless, more studies discussing the direct effect of mixtures of pesticides on nontarget biota are needed, given that they are commonly applied concurrently and that this information is more environmentally relevant [13].

Once pesticides' uptake by biota occurs, they may be biotransformed for subsequent excretion, eliminated unmetabolized, or bioaccumulated. Bioaccumulation occurs when the rate of contaminant entry is significantly higher than metabolization and elimination [14]. Cypermethrin and chlorpyrifos are potentially bioaccumulative in biota because both have log octanol-water partition coefficients $\left(\log K_{\text {OW }}\right)$ above $3\left(\log K_{\text {OW }}\right.$ cypermethrin $=6.6 ; \log K_{\mathrm{OW}}$ chlorpyrifos $=4.9$ [15]).

In laboratory studies it is possible to calculate the bioconcentration factor (BCF), to express the degree in which bioconcentration occurs [16]. Bioconcentration is the process by which a chemical substance is absorbed by an organism from the environment only through its respiratory and dermal surface, without considering the diet exposure. Previous studies reported $\mathrm{BCF}$ values of cypermethrin between $372 \mathrm{~L} / \mathrm{kg}$ and $821 \mathrm{~L} / \mathrm{kg}$ in whole-body fish $[17,18]$. In addition, studies carried out with chlorpyrifos showed a wide range of BCF values between $745 \mathrm{~L} / \mathrm{kg}$ and $2406 \mathrm{~L} / \mathrm{kg}$ in whole-body fish $[19,20]$. Even 
though potential for accumulation of pesticides has been addressed, experimental bioconcentration test results in native biota are still scarce in the literature.

Metabolization reactions are catalyzed by enzymes present primarily in the liver, although significant activity has been reported in other tissues such as the brain and intestine [21]. In fish, the enzymes responsible for the phase I biotransformation of a large number of xenobiotics belong mainly to the cytochrome $\mathrm{P} 450$ family. In particular, the isoenzyme cytochrome P4501A (CYP1A), including the CYP1A1 and CYP1A2 genes, is a wellknown biomarker of environmental pollution [14]. Moreover, the enzyme glutathione-S-transferase (GST) is involved in phase II biotransformation reactions catalyzing the conjugation of endogenous and exogenous compounds with the peptide glutathione. Finally, the $\mathrm{P}$-glycoprotein $(P-g p)$ is a carrier protein belonging to the system of multixenobiotic resistance that would be considered phase III biotransformation reaction and be involved in the excretion of compounds from the cell_-either the parental structure or metabolites produced after phase I reactions [22].

Edwards and Millburn [23] and Carriquiriborde et al. [24] studied the metabolic profile in the rainbow trout Salmo gairdneri and in the South American fish Odontesthes bonariensis after oral and waterborne exposure, respectively, to cypermethrin. In both studies, residues of the pesticide or its metabolites were detected, but the performance of phases I, II, and III biotransformation reactions was not evaluated. Probable biotransformation pathways for cypermethrin in fish are shown in Figure 1.

On the other hand, chlorpyrifos can also be accumulated in different tissues of fish after waterborne exposure. Barron et al. [25] studied the tissue distribution and metabolism of chlorpyrifos in channel catfish Ictalurus punctatus after 24-h exposure to $12 \mu \mathrm{g} / \mathrm{L}$ of the pesticide. The authors found the highest concentration of chlorpyrifos in fat and the lowest in muscle, whereas in the whole fish the mean chlorpyrifos concentration was $612 \pm 64 \mu \mathrm{g} / \mathrm{kg}$. In addition, the metabolites of chlorpyrifos, trichloropyridinol, and trichloropyridinol glucuronide, were measured in blood, urine, and bile. Wang et al. [26] measured chlorpyrifos and its metabolite, chlorpyrifos-oxon, in both the spleen and the kidney of Cyprinus carpio, after a $40-\mathrm{d}$ exposure to $1.16 \mu \mathrm{g} / \mathrm{L}$ of chlorpyrifos and $1.13 \mu \mathrm{g} / \mathrm{L}$ of atrazine and a chlorpyrifos mixture. In addition, accumulation of chlorpyrifos was measured in Gambusia affinis exposed to $60 \mu \mathrm{g} / \mathrm{L}$ of this insecticide for $20 \mathrm{~d}$, and reported the maximum amount of bioaccumulation on day 4 . The maximum accumulation of chlorpyrifos was in viscera, followed by head, and body, with average BCF values of $109 \mathrm{~L} / \mathrm{kg}, 9 \mathrm{~L} / \mathrm{kg}$, and $4 \mathrm{~L} / \mathrm{kg}$, respectively [27]. To the extent of our knowledge, there is only limited information concerning accumulation of cypermethrin and chlorpyrifos, particularly at environmentally

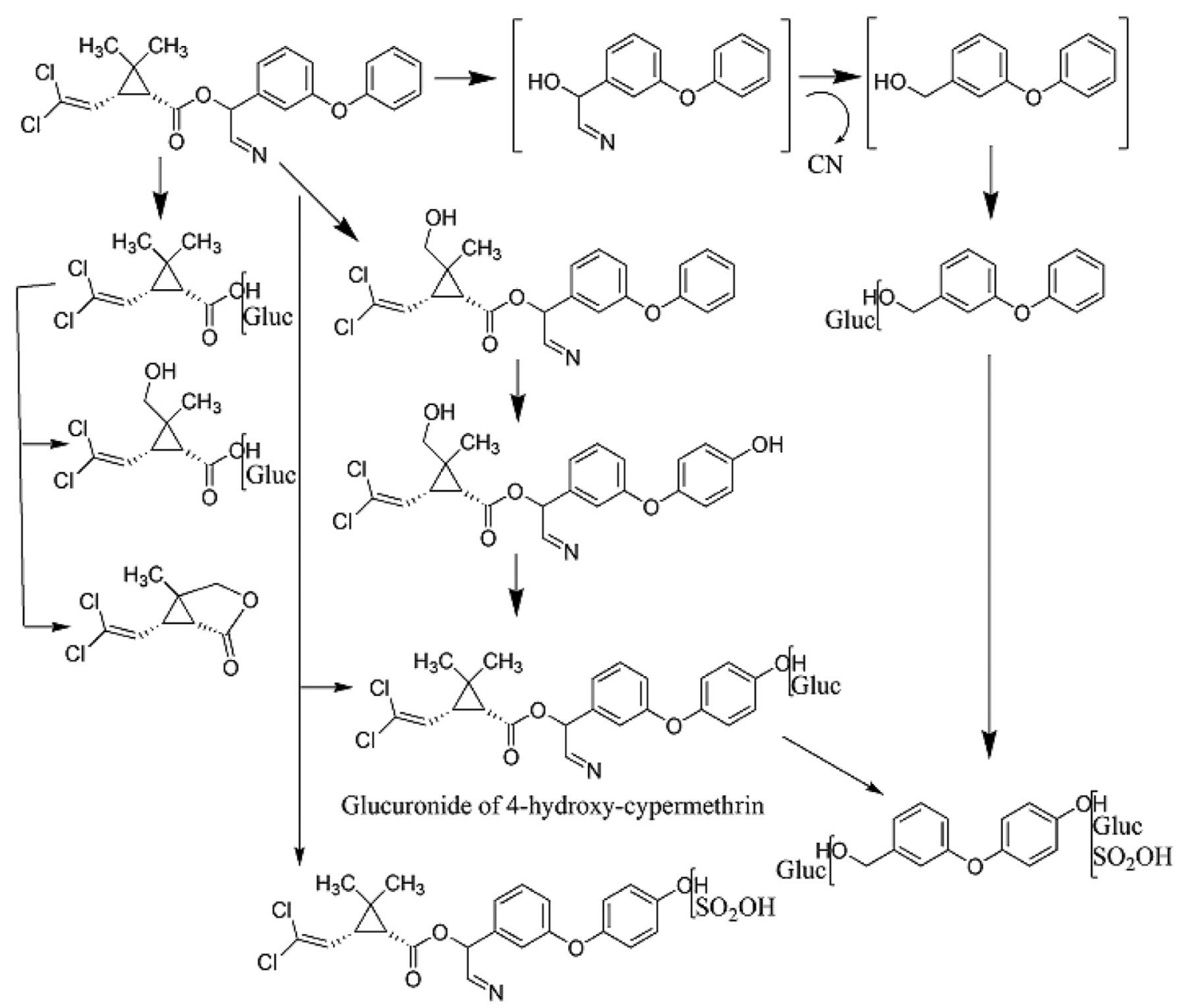

Sulfate of 4-hydroxy-cypermethrin

Figure 1. Pathways of biotransformation of cypermethrin proposed by Edwards and Millburn [23] and updated by Carriquiriborde et al. [24], according to the metabolites found in the bile of rainbow trout and pejerrey, respectively. 
relevant concentrations. Moreover, bioaccumulation data of cypermethrin and chlorpyrifos after exposure to their mixtures has not been reported. Finally, Xing et al. [28,29] described that the herbicide atrazine and chlorpyrifos caused different responses in the activity of biotransformation enzymes when $C$. carpio was exposed to these compounds individually or in mixtures. The authors reported an increasing trend for the expression and activity of the biotransformation enzymes of phase I with accumulation of the pesticides and their metabolites in the liver when fish were exposed to $4.28 \mu \mathrm{g} / \mathrm{L}$ of atrazine, $1.16 \mu \mathrm{g} / \mathrm{L}$ of chlorpyrifos, and $1.13 \mu \mathrm{g} / \mathrm{L}$ of their mixture [29]. Moreover, a significant decrease was observed in the GST activity in animals exposed to $428 \mu \mathrm{g} / \mathrm{L}$ of atrazine, $116 \mu \mathrm{g} / \mathrm{L}$ of chlorpyrifos, and $113 \mu \mathrm{g} / \mathrm{L}$ of their mixture [28]. Proposed biotransformation pathways for chlorpyrifos in fish are shown in Figure 2.

The native fish Jenynsia multidentata (Cyprinodontiformes, Anablepidae) presents a wide distribution in South America [30]. It is a small ( $\sim 4 \mathrm{~cm}$ in length), freshwater, viviparous species with external sexual dimorphism. It is also easy to transport and keep in laboratory conditions. This species is considered to be a good experimental model; it was used to evaluate the effects of lindane, glyphosate, endosulfan, cypermethrin, and chlorpyrifos on different biological processes [31].

Accordingly, the aim of the present study was to evaluate the bioaccumulation of cypermethrin and chlorpyrifos when the native fish $J$. multidentata was exposed to these pesticides individually or in mixtures of pure compounds (technical) and commercial products at environmentally relevant levels. Biotransformation biomarkers were also measured to look for evidence of metabolic pathways of both pesticides in this native species.

\section{MATERIALS AND METHODS}

Fish

Individual $J$. multidentata were captured by backpack electrofisher equipment (LR-20B; Smith-Root) from an unpolluted area of the Yuspe River, Córdoba, Argentina [32]. Specimens of adult females were transported to the laboratory and acclimated to laboratory conditions for $2 \mathrm{wk}$ before the experiments. They were maintained in a temperature-controlled room at $21 \pm 2{ }^{\circ} \mathrm{C}$ and in a 12:12-h light:dark photoperiod. Fish were of homogeneous size (mean standard length $4.2 \pm 0.5 \mathrm{~cm}$ and mean body wt $0.8 \pm 0.3 \mathrm{~g}$ ). During acclimation and exposure periods, they were fed ad libitum once a day with commercial fish pellets (TetraMin) and the remainder of the food was removed after feeding.

\section{Exposure conditions and design}

After the acclimatization period, fish (mean standard length $4.2 \pm 0.5 \mathrm{~cm}$ and mean body wt $0.8 \pm 0.3 \mathrm{~g}$ ) were exposed for $96 \mathrm{~h}$ to Control, $0.04 \mu \mathrm{g} / \mathrm{L}$ of cypermethrin (99\%; SigmaAldrich), and $0.4 \mu \mathrm{g} / \mathrm{L}$ of chlorpyrifos (98\%; Sigma-Aldrich) singly (cypermethrin or chlorpyrifos) and in a technical mixture (cypermethrin + chlorpyrifos; hereafter referred to as technical

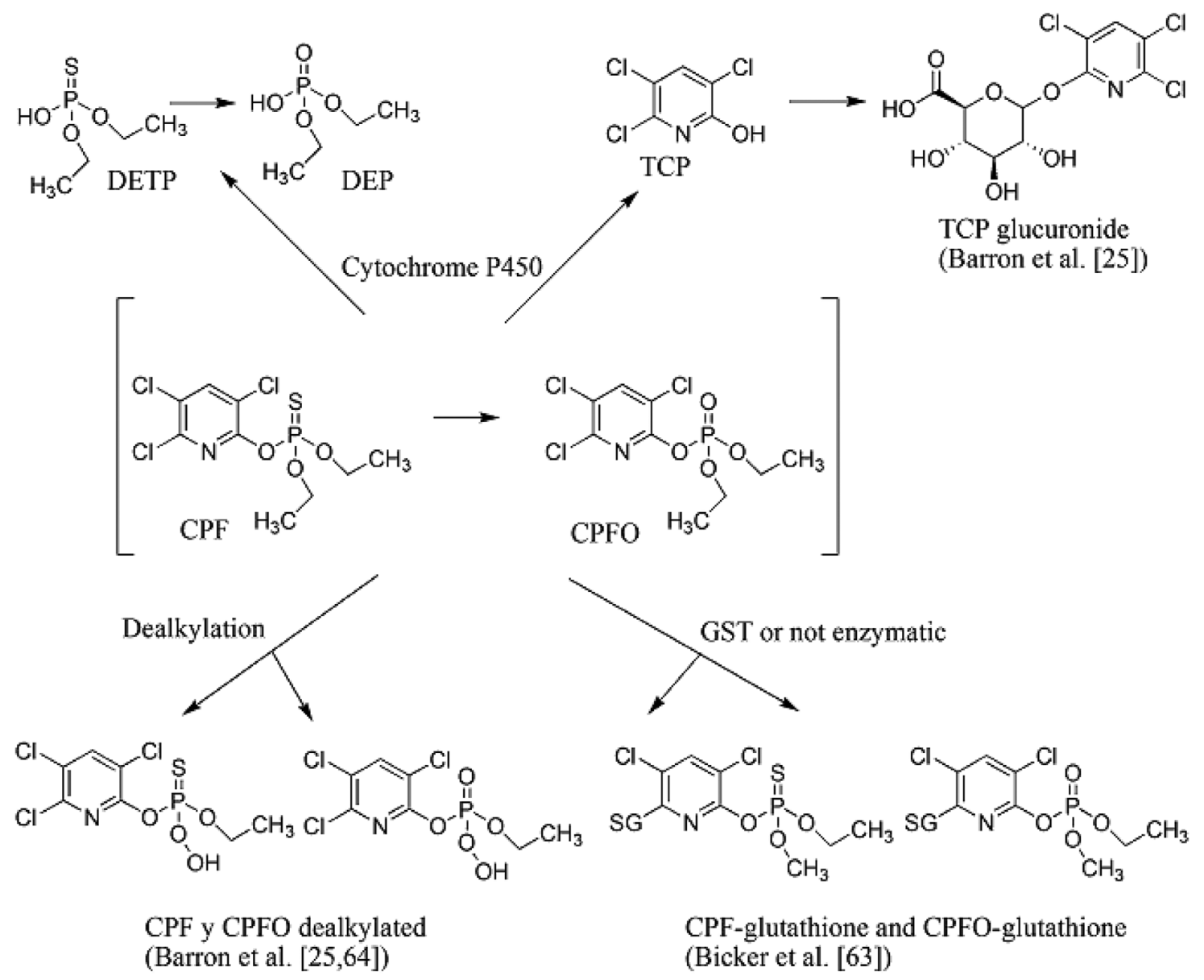

Figure 2. Pathway of biotransformation of chlorpyrifos proposed by Bicker et al. [63] and modified according to Barron et al. [25,64] and Hayes [21]. CPF: chlorpyrifos; CPFO: chlorpyrifos-oxon; TCP: 3,5,6 trichloropyridinol; DETP: diethyl thiophosphate; DEP: diethyl phosphate; GST: glutathione S-transferase. 
mixture). In addition, the same mixtures, $0.04 \mu \mathrm{g} / \mathrm{L}$ of cypermethrin (25\% Glacoxan; Punch Química) and $0.4 \mu \mathrm{g} / \mathrm{L}$ of chlorpyrifos (40\% Clorfox; GLEBA) of a commercial product were tested (hereafter referred to as commercial product).

The exposure concentrations were selected taking into account 3 main criteria: 1) concentrations of cypermethrin and chlorpyrifos in natural freshwaters (cypermethrin $=0.2 \mathrm{ng} / \mathrm{L}-$ $3.5 \mu \mathrm{g} / \mathrm{L}$, chlorpyrifos $=0.2 \mathrm{ng} / \mathrm{L}-17 \mu \mathrm{g} / \mathrm{L}$ [4-7]); 2) for 96-h medium lethal concentrations (96-h LC50) available for Poecilia reticulata, which belong to the same order as J. multidentata (Cyprinodontiformes, cypermethrin 96-h LC50 x2009; $=21.4 \mu \mathrm{g} / \mathrm{L}$ [33], and chlorpyrifos 96-h LC50 $=176 \mu \mathrm{g} / \mathrm{L}[34])$, the sublethal concentrations $0.2 \%$ and $2 \%$ of the 96-h LC50 were chosen; and 3) exposure to equitoxic mixture as well as in a proportion usually used for agricultural purposes (0.002 and 0.02 toxic units according to 96-h LC50 for $P$. reticulata and a proportion of 5 cypermethrin, 50 chlorpyrifos [8]).

All experiments were conducted in 5-L glass aquariums (1 fish per liter) containing aquarium-prepared water (distilled water containing $100 \mathrm{mg} / \mathrm{L}$ of sea salt, $200 \mathrm{mg} / \mathrm{L}$ of $\mathrm{CaCl}_{2}$, and $103 \mathrm{mg} / \mathrm{L}$ of $\mathrm{NaHCO}_{3}$ [35]). Pesticides dissolved in acetone were added to the aquarium water. Acetone was also added to the control condition. The final concentration of dissolvent was the same in all the treatments and was always lower than $0.05 \%$.

Each treatment was carried out in 5 independent exposure tanks, meaning 25 specimens per condition and a total of 125 individuals for the present study.

Because of the unstable nature of cypermethrin and chlorpyrifos during the exposure conditions, a semistatic exposure system was used. New exposure tanks were prepared every $24 \mathrm{~h}$. Fish were transferred daily to new tanks $10 \mathrm{~min}$ after the tank was prepared.

During the exposure period, aquarium water showed the following conditions: temperature $23.5 \pm 0.1^{\circ} \mathrm{C}, \quad \mathrm{pH}$ $7.92 \pm 0.06$, dissolved oxygen $6.73 \pm 0.09 \mathrm{mg} / \mathrm{L}$, and conductivity $948 \pm 33 \mu \mathrm{S} / \mathrm{cm}$.

After the exposure period, the animals were euthanized and the liver, intestine, gills, brain, and muscle were taken and stored at $-80{ }^{\circ} \mathrm{C}$ until pesticide and enzyme analysis. For $C Y P 1 A 1$ and $P$-gp quantification, organs were snap-frozen in liquid nitrogen and stored in ribonucleic acid (RNA) later (QIAGEN) at $80^{\circ} \mathrm{C}$ until analysis. From the 25 organisms exposed per treatment, 15 were used for measuring pesticide accumulation, 5 were utilized for measuring enzyme activity (GST), and 5 were used to evaluate expression of $C Y P 1 A 1$ and $P-g p$.

\section{Quantification of cypermethrin and chlorpyrifos}

Aquarium water samples. The measurement of cypermethrin and chlorpyrifos in the exposure medium was performed by solid phase extraction-solid phase microextraction-gas chromatography coupled to mass spectrometry, according to Bonansea et al. [4].

The cypermethrin and chlorpyrifos concentrations were determined in water samples collected in the aquariums $30 \mathrm{~min}$ after the preparation of the tanks $(t=0 \mathrm{~h})$ and before the daily transference of fish to new tanks $(t=24 \mathrm{~h})$.

\section{Fish tissue samples}

Tissue sample preparation. Fish tissues were pooled to get enough quantity for analysis ( 3 pools of 5 individuals each taken randomly from 5 exposure tanks conducted for each treatment). Approximately $10 \mathrm{mg}$ to $500 \mathrm{mg}$ of pooled tissue samples were homogenized in a mortar with $3 \mathrm{~g}$ of anhydrous sodium sulfate.
Then $2 \mathrm{~g}$ of Florisil (60 mesh-100 mesh) were added and the samples were homogenized again. The mixture of sorbent material and fish tissue was packed into a $10-\mathrm{mL}$ cartridge that was fitted with $3 \mathrm{~g}$ of alumina for sample clean-up. The elution was carried out with $10 \mathrm{~mL}$ of ethyl acetate. Subsequently, the elute was evaporated under nitrogen current until dry, redissolved with $0.5 \mathrm{~mL}$ of ethyl acetate, and transferred to an auto sampler vial for gas chromatography coupled with electron capture detector (Agilent) analysis. Polychlorinated biphenyl \#103 was added to each vial as an internal standard. The extracts with cypermethrin or chlorpyrifos concentrations above the detection limit were afterward concentrated until dry, and redissolved in $0.3 \mathrm{~mL}$ of acetonitrile (ultrapure water, 70/30, v/ v) to be confirmed by high-performance liquid chromatography coupled to mass spectrometry electrospray ionization source using a quadrupole time-of-flight analyzer (HPLC-ESI-qTOF) (Agilent-Bruker Daltonics).

Recovery percentages of cypermethrin and chlorpyrifos were previously evaluated from spiked samples at $6.7 \mu \mathrm{g}$ of cypermethrin/ $\mathrm{kg}$ or chlorpyrifos/kg and $667 \mu \mathrm{g}$ of cypermeth$\mathrm{rin} / \mathrm{kg}$ or chlorpyrifos/kg wet weight, obtaining $71 \pm 3 \%$ for cypermethrin and $84 \pm 4 \%$ for chlorpyrifos.

Instrument and operational conditions. Analyses were performed on a gas chromatograph (Agilent 6890) equipped with a ${ }^{63} \mathrm{Ni} \mu$-electron capture detector (Agilent). One microliter of the sample was injected and separated on a (5\%-phenyl)-methylpolysiloxane capillary column (HP-5; Agilent, $30 \mathrm{~m} \times 0.25 \mathrm{~mm}$ ID, $25-\mu \mathrm{m}$ film thickness) with helium as carrier gas at a flow rate of $7 \mathrm{~mL} / \mathrm{min}$. The oven temperature was programmed starting at $160^{\circ} \mathrm{C}$ and held for $1 \mathrm{~min}$, followed by increases of $17^{\circ} \mathrm{C} / \mathrm{min}$ up to $200^{\circ} \mathrm{C}, 6^{\circ} \mathrm{C} / \mathrm{min}$ up to $270^{\circ} \mathrm{C}$ and held for $4 \mathrm{~min}$, with a total acquisition program of $19.02 \mathrm{~min}$. The limits of detection (LODs) and limits of quantification (LOQs) of the method were experimentally estimated as the concentration of analyte giving a signal-to-noise ratio of 3 and 10 , respectively [36]. The limits obtained in tissue samples for both insecticides were $\mathrm{LOD}=0.5 \mu \mathrm{g} / \mathrm{kg}$ and $\mathrm{LOQ}=2 \mu \mathrm{g} / \mathrm{kg}$.

The presence of cypermethrin and chlorpyrifos in tissues was confirmed by HPLC-ESI-qTOF (Agilent-Bruker Daltonics). The liquid chromatography separation was performed on a C-18 column (Kinetex; Phenomenex) at a flow rate of $0.3 \mathrm{~mL} / \mathrm{min}$. Binary mobile phases used were $0.1 \%$ formic acid in acetonitrile and $0.1 \%$ formic acid in water. Accurate mass spectra were recorded across the range $80 \mathrm{~m} / \mathrm{z}$ to $800 \mathrm{~m} / \mathrm{z}$. An internal calibrant ( $20 \mathrm{mM}$ of sodium formate solution) was delivered by an external syringe pump during $1 \mathrm{~min}$ in each run for postrun mass internal calibration. The instrument was operated in full-scan mode. Recorded data were processed with the Compass 1.3 software (Bruker Daltonics). Positive identifications of target compounds were based on: 1) accurate mass measurement of the base ion with a mass error $<10 \mathrm{ppm}$ (molecular ions $[\mathrm{M}+\mathrm{H}]^{+}$in PI mode); 2) accurate mass of 2 product ions (cypermethrin $\mathrm{C}_{22} \mathrm{H}_{19} \mathrm{Cl}_{2} \mathrm{NO}_{3} \mathrm{~m} / \mathrm{z}$ : 416.084 and 418.081; chlorpyrifos $\mathrm{C}_{9} \mathrm{H}_{11} \mathrm{Cl}_{3} \mathrm{NO}_{3} \mathrm{PS} \mathrm{m} / \mathrm{z}$ : 349.936 and 351.933); and 3) comparison of the retention time of the analyte in the sample with that corresponding to pure compounds $( \pm 2 \%)$. The LODs and LOQs obtained in tissue samples were for cypermethrin: $\mathrm{LOD}=5 \mu \mathrm{g} / \mathrm{kg}$ and $\mathrm{LOQ}=15 \mu \mathrm{g} / \mathrm{kg}$, and for chlorpyrifos: $\mathrm{LOD}=3 \mu \mathrm{g} / \mathrm{kg}$ and $\mathrm{LOQ}=10 \mu \mathrm{g} / \mathrm{kg}$. All measurements were performed in triplicate.

\section{Enzyme analysis}

Enzyme extracts were prepared from individual intestine, liver, gills, brain, and muscle (5 organs, not pooled, coming from 5 specimens taken randomly from 5 exposure tanks 
conducted for each treatment) according to Monferrán et al. [37]. Thus cytosolic and microsomal protein fractions were obtained from each sample. Enzymatic activities were determined by spectrophotometry, using a microplate reader (Synergy BioTek). The activity of soluble GST and membranebound GST (EC 2.5.1.18) was determined using 1-Chloro-2,4dinitrobenzene (CDNB) as substrate [38]. The enzymatic activity was calculated in terms of the protein content of the sample, measured at $595 \mathrm{~nm}$ by the Bradford method [39], and it is reported in nanokatals per milligram of protein (nkat $\mathrm{mg} / \mathrm{prot}$ ), where $1 \mathrm{~kat}$ is the conversion of $1 \mathrm{~mol}$ of substrate per second. Each enzymatic measurement was carried out in triplicate.

\section{Expression of CYP1A1 and P-gp}

For $C Y P 1 A 1$ and $P$-gp quantification, intestine, liver, gills, brain, and muscle were analyzed. The processed tissues came from 5 specimens taken randomly from 5 exposure tanks conducted for each treatment. Total RNA was extracted from tissues by the guanidine thiocyanate-phenol chloroform extraction method in accordance with Chomczynski and Sacchi [40]. Nonspecific reverse transcription was performed with an Oligo $(\mathrm{dT})_{15}$ primer (Biodynamics), and Moloney Murine Leukemia Virus reverse transcriptase (Invitrogen) [41]. Quantitative polymerase chain reaction was performed with a Bio-Rad iQ cycler and was used to amplify and measure the transcript abundance of $C Y P 1 A l$ and $P$ - $g p$ in all studied tissues. We have previously characterized the partial cDNA sequences for $C Y P 1 A 1$ and $P$-gp of $J$. multidentata $[41,42]$ (GenBank accession numbers are EF362746 and EF362745, respectively), and have designed specific $J$. multidentata primers for real-time polymerase chain reaction (CYPIAl forward: 5'-CTGGATCGAAC TCCTACTATCACTGA-3', reverse: $5^{\prime}$-GCAGTGTGGGATTGTGAAAGGTA-3'; $P$ - $g p$ forward: 5'-CTGCACGCTAGCGGAAAAC- $3^{\prime}$, reverse: 5'-CCTCTATCTCCTCCATGGTCA CA- $\left.3^{\prime}\right)$. The primers were designed using Primer Express Software (Applied Biosystems), and obtained from SigmaAldrich. The use of $J$. multidentata $\beta$-actin [41] as a reference gene was tested. Relative gene expression was analyzed by using the standard curve method and was carried out in triplicate.

\section{Bioconcentration factor}

Bioconcentration factors (in $\mathrm{L} / \mathrm{kg}$ ) of cypermethrin and chlorpyrifos in $J$. multidentata tissues at each exposure treatment were estimated as the ratio between the concentration of the corresponding pesticide in a fish organ $(\mu \mathrm{g} / \mathrm{kg}$ wet $\mathrm{wt})$ divided by the measured pesticide concentration in exposure water samples $(\mu \mathrm{g} / \mathrm{L})$ [43].

The pesticide concentration in whole-fish body was estimated as the ratio between the addition of the measured quantities of the corresponding pesticide in each organ $(\mu \mathrm{g})$ to the addition of the mean wet weight of each organ measured [44].

\section{Statistical analysis}

All values are expressed as mean \pm standard deviation. Normal distribution of data was analyzed by the Shapiro-Wilk test, whereas Levene's test was used to test the homogeneity of variance. To evaluate the differences of enzymes' activity measured, as well as CYPIAl and P-gp expression, one-way analysis of variance followed by the Tukey test were performed to compare among treatments. When the data showed abnormal distribution, they were subjected to a nonparametric statistical analysis (Kruskal-Wallis test) followed by Dunn's test. The InfoStat/P software [45] was employed in all cases. Significance was accepted at $p<0.05$.

\section{RESULTS AND DISCUSSION}

\section{Pesticide concentrations in water samples}

Initial concentrations of insecticides in aquarium water were measured in all treatments. However, no significant differences between concentrations of chlorpyrifos or cypermethrin in different treatments were observed. Consequently, the averages obtained from all treatment samples are reported to simplify subsequent calculations. Cypermethrin and chlorpyrifos concentrations at $t=0 \mathrm{~h}$ were cypermethrin $=0.04 \pm 0.01 \mu \mathrm{g} / \mathrm{L}$ and chlorpyrifos $=0.31 \pm 0.03 \mu \mathrm{g} / \mathrm{L}$. The decay in pesticide concentrations after $24 \mathrm{~h}(t=24 \mathrm{~h})$ was $49 \%$ and $81 \%$ for cypermethrin and chlorpyrifos, respectively, justifying the daily renewal of the exposure medium. Insecticide concentrations in control aquariums were below the LODs of the method (cypermethrin $=0.2 \mathrm{ng} / \mathrm{L}$; chlorpyrifos $=0.2 \mathrm{ng} / \mathrm{L}$ ).

\section{Accumulation and biotransformation response}

According to van de Oost et al. [14], bioaccumulation depends on the balance of uptake, biotransformation, and elimination. The accumulations of cypermethrin and chlorpyrifos were observed in the intestine, liver, gills, and muscle of J. multidentata (Table 1). In contrast, the insecticides were always below the LOD in the brain. Moreover, the distribution of the insecticides among tissues was different, whether the exposure was made with pesticides individually or in mixtures.

To contribute to the understanding of the mechanisms involved in the biotransformation of cypermethrin and chlorpyrifos in different organs of J. multidentata, enzymes of phases I, II, and III were evaluated as biomarkers of these processes; the results are shown in Table 2. Expression of $C Y P 1 A 1$ and $P$ - $g p$ was not measured in muscle because low yields in RNA extractions were obtained.

Cypermethrin exposure. When J. multidentata was exposed to cypermethrin for $96 \mathrm{~h}$, the insecticide was only detected in muscle (Table 1). Meanwhile, fish exposed to cypermethrin significantly increased the CYP1A1 expression in the liver (1.9-fold change compared with control, Table 2 ). In addition, a significant decrease (0.4- to 0.6-fold change compared with control) was evidenced in the activity of GST microsomal (GSTm) and GST cytosolic (GSTc) in the intestine, brain, and muscle as well as GSTm in the liver. The expression of $P$ - $g p$ did not indicate significant differences in any of the organs studied compared with the control.

Edwards and Millburn [23] have reported the accumulation of cypermethrin in the rainbow trout Salmo gairdneri when it was exposed to the pesticide for $24 \mathrm{~h}$. However, the pesticide levels were higher in viscera than in other parts of the fish body (including the muscle). The differences with our results could be the result of different exposure concentrations (Edwards and Millburn [23] $=5$ and $10 \mu \mathrm{g} / \mathrm{L}$; the present study $=0.04 \mu \mathrm{g} / \mathrm{L}$ ) and a faster metabolism of cypermethrin in other organs than in muscle. In fish, the main route of cypermethrin biotransformation described by other authors is a hydroxylation followed by conjugation with sulfate or glucuronic acid [23,24]. This oxidation may be mediated by the cypermethrin enzyme system (Figure 1). Moreover, there is some evidence that cypermethrin is a good substrate for the CYP1Al isoform, which has been demonstrated for humans and rats [46]. Therefore, this mechanism may be occurring in the liver of $J$. multidentata and 
would be sufficient to prevent the accumulation of the insecticide in the liver, as well as in other organs. The exposure of J. multidentata to $1 \mu \mathrm{M}$ of $\beta$-naphthoflavon for $24 \mathrm{~h}$ has also markedly induced the expression of CYP1A in the gills and liver of this fish [47]. The occurrence of cypermethrin in muscle could be associated with a lower capacity of this organ to biotransform, when compared with other organs. For instance, the lower capacity of muscle to biotransform exogenous compounds has been reported in the neotropical silverside fish $O$. bonariensis exposed to microcystins [48].

Glutathione conjugation by GST has not been reported in previous studies of cypermethrin metabolism, both in mammals and fish $[23,24,49]$. Our results partially coincide with these reports because no increase was observed in the enzyme activity, but inhibition of GST was evidenced in various organs of $J$. multidentata. When inhibition takes place, the enzymatic activity is blocked. This could be explained by several hypotheses. Cypermethrin or its metabolites may be competing with GST substrates for the active sites on the GST enzyme [50]. Alternatively, a decrease in GST protein synthesis can occur as a result of damage generated in cells by increased reactive oxygen species (ROS) produced by cypermethrin [51]. Inhibition may also be caused by a covalent modification of the enzyme by the insecticide, leading to an irreversible loss of activity [52]. Similar results were observed in the brain of rats exposed to cypermethrin [51].

Chlorpyrifos exposure. Fish exposed to chlorpyrifos showed concentrations of this pesticide in the following descending order: intestine $>$ liver $>$ gills $($ Table 1). The distribution of chlorpyrifos in different tissues of J. multidentata presents a typical pattern of hydrophobic compounds. Moreover, a similar distribution was reported in the catfish $I$. punctatus and the mosquitofish G. affinis exposed to the same insecticide [25,27]. The occurrence of chlorpyrifos in the intestine and gills could mean 2 possible uptake routes for dissolved chlorpyrifos: by the gastrointestinal tract through drinking the exposure medium, or by the gills during ventilation. The adsorption of chlorpyrifos from fish food is less possible because fish were fed for a short period and in small quantities. This hypothesis agrees with that expressed by Bruggeman et al. [53].

On the other hand, the presence of chlorpyrifos in the intestine and gills, which are highly vascularized, could be a result of desorption from the blood stream for its excretion (by feces or during ventilation). However, according to Welling and de Vries [54], the elimination of unchanged chlorpyrifos is insignificant in comparison with metabolic degradation.

The liver is located in a strategic position within the organisms, receiving a large volume of blood that contributes to the distribution of chemical compounds and their metabolites to other organs. In addition, the liver has an abundant reserve of nonspecific enzymes, giving it the capacity to metabolize a broad spectrum of organic compounds [55].

In fish exposed to chlorpyrifos, no changes were evidenced in the expression of CYPIAl in any of the organs when compared with control. On the other hand, a significant decrease was observed for GSTc and GSTm activity in the intestine (0.5fold and 0.6-fold change compared with control) and the brain (0.4-fold change compared with control), as well as for GSTm activity in the liver and muscle (1.8-fold and 2-fold change compared with control, respectively). In contrast, in the gills of J. multidentata, GSTm activity significantly increased (0.2-fold change compared with control), whereas only in the liver a 
Table 2. Relative cytochrome P4501A1 and P-glycoprotein multidrug transporter protein gene expression, and gluthatione-S-transferase cytosolic (GSTc) and gluthatione-S-transferase microsomal (GSTm) activity in the intestine, liver, gills, brain, and muscle of Jenynsia multidentata after exposure to sublethal concentrations of cypermethrin and chlorpyrifos singly and in mixtures for $96 \mathrm{~h}^{\mathrm{a}}$

\begin{tabular}{|c|c|c|c|c|c|}
\hline Treatments & Intestine & Liver & Gills & Brain & Muscle \\
\hline \multicolumn{6}{|l|}{ 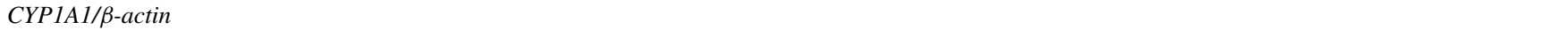 } \\
\hline Control & $0.6 \pm 0.1 \mathrm{BC}$ & $0.7 \pm 0.2 \mathrm{~B}$ & $1.7 \pm 0.7 \mathrm{~B}$ & $0.8 \pm 0.3 \mathrm{~A}$ & ND \\
\hline $\mathrm{CYP}+\mathrm{CPF}$ & $0.61 \pm 0.06 \mathrm{C}$ & $1.3 \pm 0.3 \mathrm{C}$ & $0.9 \pm 0.5 \mathrm{~A}$ & $0.6 \pm 0.1 \mathrm{~A}$ & ND \\
\hline Product & $0.24 \pm 0.03 \mathrm{~A}$ & $0.25 \pm 0.07 \mathrm{~A}$ & $2.0 \pm 0.3 \mathrm{~B}$ & $1.4 \pm 0.6 \mathrm{~A}$ & ND \\
\hline \multicolumn{6}{|c|}{ GSTc (nkat/mg protein) } \\
\hline $\mathrm{CPF}$ & $2 \pm 1 \mathrm{~A}$ & $3.4 \pm 0.4$ & $1.1 \pm 0.2$ & $3.1 \pm 0.3 \mathrm{~A}$ & $0.3 \pm 0.1 \mathrm{BC}$ \\
\hline $\mathrm{CYP}+\mathrm{CPF}$ & $3 \pm 1 \mathrm{AB}$ & $4.1 \pm 0.6$ & $1.1 \pm 0.2$ & $3.2 \pm 0.6 \mathrm{~A}$ & $0.3 \pm 0.1 \mathrm{AB}$ \\
\hline Product & $3 \pm 1 \mathrm{BC}$ & $4.5 \pm 0.8$ & $1.0 \pm 0.2$ & $3.8 \pm 0.5 \mathrm{~B}$ & $0.3 \pm 0.1 \mathrm{AB}$ \\
\hline \multicolumn{6}{|c|}{ GSTm (nkat/mg protein) } \\
\hline Control & $2.0 \pm 0.5 \mathrm{~B}$ & $2.4 \pm 0.3 \mathrm{~B}$ & $0.5 \pm 0.1 \mathrm{~B}$ & $2.0 \pm 0.5 \mathrm{~B}$ & $0.4 \pm 0.1 \mathrm{C}$ \\
\hline CYP & $0.9 \pm 0.2 \mathrm{~A}$ & $1.4 \pm 0.7 \mathrm{~A}$ & $0.6 \pm 0.1 \mathrm{BC}$ & $1.1 \pm 0.4 \mathrm{~A}$ & $0.2 \pm 0.1 \mathrm{AB}$ \\
\hline $\mathrm{CPF}$ & $0.8 \pm 0.2 \mathrm{~A}$ & $1.3 \pm 0.2 \mathrm{~A}$ & $0.6 \pm 0.1 \mathrm{C}$ & $1.2 \pm 0.1 \mathrm{~A}$ & $0.2 \pm 0.1 \mathrm{~A}$ \\
\hline \multicolumn{6}{|l|}{$P$-gp/ $\beta$-actin } \\
\hline CYP & $1.0 \pm 0.2 \mathrm{~B}$ & $0.8 \pm 0.2 \mathrm{~A}$ & $1.4 \pm 0.4 \mathrm{AB}$ & $0.6 \pm 0.1 \mathrm{BC}$ & ND \\
\hline $\mathrm{CPF}$ & $0.9 \pm 0.2 \mathrm{AB}$ & $1.7 \pm 0.6 \mathrm{~B}$ & $1.3 \pm 0.2 \mathrm{AB}$ & $0.57 \pm 0.05 \mathrm{BC}$ & ND \\
\hline $\mathrm{CYP}+\mathrm{CPF}$ & $1.0 \pm 0.2 \mathrm{~B}$ & $0.9 \pm 0.2 \mathrm{~A}$ & $0.9 \pm 0.4 \mathrm{~A}$ & $0.41 \pm 0.03 \mathrm{~A}$ & ND \\
\hline Product & $0.6 \pm 0.1 \mathrm{~A}$ & $0.9 \pm 0.1 \mathrm{~A}$ & $1.8 \pm 0.4 \mathrm{~B}$ & $0.64 \pm 0.03 \mathrm{C}$ & ND \\
\hline
\end{tabular}

${ }^{\mathrm{a}}$ Data are expressed as mean \pm 1 standard deviation. Capital letters indicate significant differences among treatments, for each column and into the same organ $(p<0.05)$. Cypermethrin $0.04 \mu \mathrm{g} / \mathrm{L}$; chlorpyrifos $0.4 \mu \mathrm{g} / \mathrm{L}$; cypermethrin + chlorpyrifos $0.04 \mu \mathrm{g} / \mathrm{L}$ plus $0.4 \mu \mathrm{g} / \mathrm{L}$ in a technical mixture. Product: cypermethrin $0.04 \mu \mathrm{g} / \mathrm{L}$ plus chlorpyrifos $0.4 \mu \mathrm{g} / \mathrm{L}$ in a mixture of commercial products.

$\mathrm{CYP}=$ cypermethrin; $\mathrm{CPF}=$ chlorpyrifos; $C Y P 1 A 1=$ cytochrome $\mathrm{P} 4501 \mathrm{~A} 1$ gene expression; $P$ - $g p=\mathrm{P}$-glycoprotein multidrug transporter protein gene expression; $\mathrm{GST}=$ gluthatione-S-transferase; $\mathrm{ND}=$ no data

significant increase in the expression of $P$ - $g p$ was observed (0.7-fold change compared with control).

Phase I enzyme activity would be the main pathway in the biotransformation of chlorpyrifos [56]. Wheelock et al. [57] observed a decrease in protein levels of CYP1A in the species Oncorhynchus tshawytscha exposed to chlorpyrifos. Conversely, the expression of CYPIAl and the activity of cypermethrin enzymes in the species $C$. carpio were induced [29]. Given that in J. multidentata the expression of only 1 isoform of the cypermethrin system was measured, it cannot be rejected that chlorpyrifos is suffering from other phase I reactions. To confirm this mechanism in this species, an alternative would be to measure ethoxyresorufin-O-deethylase activity. Phase II conjugation by GST enzymes has been reported as a major metabolic pathway of chlorpyrifos in fish [25]. In addition, the P-gp protein would play an additional role in the detoxification of this insecticide, transporting chlorpyrifos-oxon to the extracellular space [58]. Thus the increase of both GSTm activity in the gills and $P$ - $g p$ expression in the liver could be indicating that phases II and III detoxification mechanisms are occurring in J. multidentata. Nevertheless, this increase in biotransformation pathways was not sufficient to prevent accumulation, also favored by the inhibition of the activity of GSTc in the other organs tested. The inhibition of this enzyme caused by chlorpyrifos could be a result of the same mechanisms presented for cypermethrin (see section Cypermethrin exposure) because it is a general response found for hydrophobic compounds [52,55].

Technical mixture exposure. Unexpectedly, fish exposed to the technical mixture accumulated only cypermethrin in the following descending order: liver $>$ intestine $>$ gills (Table 1).
Thus 2 aspects of these results can be discussed: the differences observed in the distribution of cypermethrin singly if compared with the exposure to cypermethrin, and the concentrations of chlorpyrifos below the LOD. As was previously stated, the only detection of cypermethrin in the muscle could be attributed to a fast metabolization of the insecticide in the other organs. In the presence of chlorpyrifos, the capability of the liver and other organs to biotransform could be diminished and, as a consequence, cypermethrin could accumulate. According to Wheelock et al. [57], the exposure of the juvenile Chinook salmon $(O$. tshawytscha) to chlorpyrifos significantly inhibited liver carboxylesterase activity at $1.2-\mu \mathrm{g} / \mathrm{L}$ and $7.3-\mu \mathrm{g} / \mathrm{L}$ chlorpyrifos dose exposure (56\% inhibition and $79 \%$ inhibition, respectively). These enzymes are, among other factors, responsible for cleavage of the ester linkage of cypermethrin, a necessary step for its detoxification. Thus inhibition in pesticide metabolism favors accumulation in its original unmetabolized chemical structure. On the contrary, chlorpyrifos below the LOD in all the studied organs could be caused by increased oxidation of the insecticide to form oxidized derivatives, not measured in the present study. This oxidation could be attributed to the presence of cypermethrin, which is known to be capable of favoring the production of ROS [59].

Fish exposed to the technical mixture of the pesticides showed a significant increase of CYPIAl expression in the liver (0.9-fold change compared with control) and a significant decrease of the expression of the same enzyme in the gills, with a 0.5 -fold change in respect to control. Moreover, significant differences were evidenced with decreased activity of GSTm and GSTc in muscle (0.25-fold change compared with control, for both enzymes' activities), of GSTc in the intestine and the 
brain (0.2-fold and 0.4-fold change compared with control, respectively), and of GSTm in the liver and gills (0.4-fold change compared with control, for both organs). A significant decrease in the expression of $P$ - $g p$ in the gills was also observed (0.5-fold change compared with control). Increased CYP1A1 expression in the liver could be caused by an attempt by that organ to metabolize cypermethrin, which was insufficient because the insecticide was bioaccumulated in the liver, intestine, and gills. The inhibition of GSTc in the intestine and the inhibition of enzymes responsible for phases I, II, and III reactions in the gills could also favor accumulation in these organs, where direct contact with the parental compounds could occur. Widespread inhibition of GST could affect the metabolism of chlorpyrifos, as observed after chlorpyrifos exposure; however, this insecticide did not accumulate. Therefore, it could be assumed that the oxidation of chlorpyrifos caused by ROS is the most important route for biotransformation of this insecticide in $J$. multidentata exposed to the technical mixture.

Commercial mixture exposure. Fish exposed to the commercial mixture of cypermethrin and chlorpyrifos showed that both pesticides accumulated in various organs of $J$. multidentata. The levels of cypermethrin were found in the following decreasing order: intestine $>$ gill (Table 1), showing the presence of the pesticide only in the possible uptake organs. In contrast to the results obtained for the technical mixture, no accumulation was observed in the liver. Regarding the bioaccumulation of chlorpyrifos, the concentration of this pesticide showed the following descending order: liver $>$ intestine $>$ gill $>$ muscle (Table 1 ), revealing a wide distribution of the insecticide in different organs of J. multidentata. As in chlorpyrifos exposure, chlorpyrifos accumulated in major uptake organs of the pollutant (the intestine and gills), as well as in the liver of the fish. In addition, when J. multidentata was exposed to the commercial product, the fish bioaccumulated chlorpyrifos in muscle. This difference could be the result of a greater ability acquired by chlorpyrifos to penetrate the membranes when it is accompanied by adjuvant compounds present in commercial formulations.

Fish exposed to cypermethrin and chlorpyrifos showed a different response pattern in biotransformation biomarkers when compared with the technical mixture. Therefore, they showed significant differences with decreased expression of CYPIA1 in the liver and intestine (0.6-fold change compared with control, for both organs), and a significant 0.8 -fold change increased CYP1Al expression in the brain, when compared with control. Furthermore, a significant decrease in GSTm and GSTc activity was observed in the muscle ( 0.75 - and 0.25 -fold change compared with control, respectively) and the gills (0.4- and 0.2 fold change compared with control, respectively), as well as of GSTm in the intestine (0.5-fold change compared with control). Relative expression of $P$ - $g p$ decreased 0.4 -fold in the intestine and increased 0.3 -fold in the brain when compared with control. Cytochrome P4501A1 expression inhibition observed in the liver could be responsible for the accumulation of chlorpyrifos through a lower efficiency of biotransformation by this route. In addition, this response could be caused by a desulfurization process of chlorpyrifos mediated by cypermethrin enzymes producing chlorpyrifos-oxon. The liberated sulfur ion could suppress cypermethrin enzymes' activity through binding to the heme group of these proteins [57,60].

The inhibition of the biotransformation system (phases I, II, and III) in the intestine could be associated with the accumulation of the 2 insecticides. Conversely, in the gills, where the 2 insecticides were accumulated, only the inhibition of GST was observed. This difference might be caused by greater accumulated concentrations of pesticides in the intestine than in the gills, or differential response of each tissue [52]. The decreased activity of GST in muscle might be diminishing the biotransformation of chlorpyrifos, thus causing the accumulation of the pesticide in this organ. The increased activity or expression of the biotransformation system (phases I and III) observed in the brain could be a result of the presence of the insecticides being metabolized effectively, preventing their accumulation in this organ. To summarize, fish exposed to the commercial product showed significant inhibition of the biotransformation system (phases I, II, and III) in the intestine, liver, muscle, and gills, causing the accumulation of 1 or 2 insecticides in these organs. Conversely, in the brain the accumulation of pesticides was avoided by increased activity or expression of the biotransformation system.

\section{$B C F$}

From the amounts of cypermethrin and chlorpyrifos quantified in each organ, the concentration of the insecticides present in the whole fish for each treatment was estimated (Figure 3). Moreover, the BCFs of cypermethrin and chlorpyrifos in different organs of $J$. multidentata were calculated and are shown in Table 3.

Fish exposed to the singular insecticides showed BCFs equaling $244 \pm 136 \mathrm{~L} / \mathrm{kg}$ in muscle for cypermethrin, and BCFs in a range from $133 \mathrm{~L} / \mathrm{kg}$ to $212 \mathrm{~L} / \mathrm{kg}$ in the intestine, liver, and gills for chlorpyrifos, indicating that the 2 compounds have the capacity to bioconcentrate in J. multidentata. This result agrees with $\log K_{\mathrm{OW}}$ values of the insecticides, both $>3\left(\log K_{\mathrm{OW}}\right.$ cypermethrin $=6.6 ; \log K_{\text {Ow }}$ chlorpyrifos $=4.9$ ). Chemical compounds with $\log K_{\mathrm{OW}}>3$ are considered bioaccumulative in an organism [15]. Furthermore, in the fish exposed to the technical mixture of these insecticides, only cypermethrin accumulated, whereas chlorpyrifos was below the LOD. The BCFs obtained for cypermethrin in J. multidentata organs were higher than those found in fish exposed to cypermethrin individually. The behavior of the compounds together, as explained in the section Technical mixture exposure, might be caused by the decreased biotransformation processes of cypermethrin and augmented oxidation of chlorpyrifos to other chemical metabolites, which were unmeasured in the present

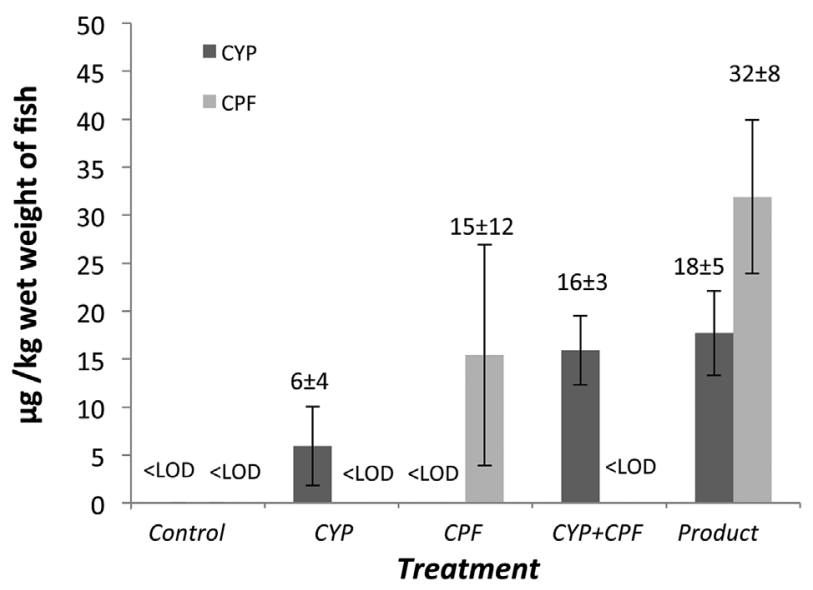

Figure 3. Estimated concentrations of cypermethrin (CYP) and chlorpyrifos $(\mathrm{CPF})$ in whole fish for each treatment. Shown as average \pm standard deviation. $\mathrm{LOD}=$ limit of detection. Product $=0.04 \mu \mathrm{g} / \mathrm{L}$ of cypermethrin $+0.4 \mu \mathrm{g} / \mathrm{L}$ of chlorpyrifos commercial mixture. 
study. Jenynsia multidentata exposed to the commercial product mixture showed BCFs for cypermethrin in the intestine and gills with higher values than those found in the exposure to the technical mixture. Bioconcentration factors for chlorpyrifos calculated for fish exposed to the commercial product varied from low values $(25 \pm 16$ and $35 \pm 19$ in muscle and gills, respectively) to middle and high values (158 \pm 92 and $1024 \pm 593$ for the intestine and liver, respectively). The BCF of chlorpyrifos in the liver of fish exposed to the commercial product was higher than the value obtained in fish exposed to chlorpyrifos individually (Table 3 ). Furthermore, in the exposure to the commercial product it was observed that $J$. multidentata bioconcentrated both compounds, unlike $J$. multidentata exposed to the mixture of pure insecticides (Figure 3). This could be associated with the presence of adjuvant compounds, substances that generally are solvents and emulsifiers, which are included in the formulations of commercial insecticides to increase their efficiency. No significant correlation was found between $\mathrm{BCF}$ and biotransformation biomarkers in the present study; however, further studies on dose-response tests could be interesting.

Other fish species of food interest, may bioconcentrate cypermethrin and chlorpyrifos in muscle similarly to J. multidentata, meaning a risk to human health. The World Health Organization jointly with the United Nations Food and Agriculture Organization established values of acceptable daily intake for cypermethrin $=20 \mathrm{mg} / \mathrm{kg}$ body weight per day [61] and for chlorpyrifos $=10 \mathrm{mg} / \mathrm{kg}$ body weight per day [62]. Considering the average value of cypermethrin and chlorpyrifos found in the muscle of the fish (Table 1), and assuming that a $70-\mathrm{kg}$ adult ingests $100 \mathrm{~g}$ of fish per day, calculations reveal consumption of $0.01 \mathrm{mg} / \mathrm{kg}$ of body weight per day, for both cypermethrin and chlorpyrifos. As a result, the calculated daily intake indicates the lack of risk associated with eating fish exposed to these concentrations of pesticide. However, in this approach the biomagnification is not considered possibly occurring under environmental conditions. From these results, there arises the need for studies of cypermethrin and chlorpyrifos accumulation in organisms with importance for human consumption. Further studies on dose-response tests should be performed to better understand these responses.

\section{CONCLUSIONS}

The native fish $J$. multidentata accumulated cypermethrin and chlorpyrifos in various organs, with higher concentrations in the liver $>$ intestine $>$ gill being lower than the quantities measured in muscle, and below the LOD in the brain. The bioaccumulation of the insecticides was detected in all treatments showing higher accumulated concentrations and distribution in the organs of fish exposed to commercial mixtures. However, the BCFs calculated in these organs were low, when compared with other exposed organisms. This effect could be a consequence of the biotransformation system showing responses of phases I and II in fish exposed to cypermethrin, phases II and III in fish exposed to chlorpyrifos, and phases I, II, and III in fish exposed to the technical mixture and the commercial product. Nevertheless, the response of the biotransformation system was insufficient to prevent accumulation of these compounds in J. multidentata.

Acknowledgment-The present study was supported by grants from the Agencia Nacional de Promoción Científica y Técnica (FONCyT-PICT 2007/1209, 2011/1597, and 2013/1348), Secretaría de Ciencia y Técnica (SECyT), and CONICET (National Research Council, Argentina). The 
present study is part of the $\mathrm{PhD}$ thesis of R.I. Bonansea, who gratefully acknowledges a fellowship from CONICET.

Data availability-Data, associated metadata, and calculation tools are available from the corresponding author (vame@fcq.unc.edu.ar).

\section{REFERENCES}

1. Ccanccapa A, Masia A, Andreu V, Pico Y. 2016. Spatio-temporal patterns of pesticide residues in the Turia and Jucar Rivers (Spain). Sci Total Environ 540:200-210.

2. Li H, Wei Y, Lydy MJ, You J. 2014. Inter-compartmental transport of organophosphate and pyrethroid pesticides in South China: Implications for a regional risk assessment. Environ Pollut 190:19-26.

3. Miclean M, Şenila L, Cadar O, Roman M, Levei E, Tanaselia C, Torok A, Majdik C. 2014. Determination of chlorpyrifos in surface water using SPE-DI-SPME/GC-ECD. Studia UBB Chemia 59:43-48.

4. Bonansea RI, Ame MV, Wunderlin DA. 2013. Determination of priority pesticides in water samples combining SPE and SPME coupled to GC-MS. A case study: Suquia River basin (Argentina). Chemosphere 90:1860-1869.

5. Mugni H, Ronco A, Bonetto C. 2011. Insecticide toxicity to Hyalella curvispina in runoff and stream water within a soybean farm (Buenos Aires, Argentina). Ecotox Environ Safe 74:350-354.

6. Jergentz S, Mugni H, Bonetto C, Schulz R. 2005. Assessment of insecticide contamination in runoff and stream water of small agricultural streams in the main soybean area of Argentina. Chemosphere 61:817-826.

7. Marino D, Ronco A. 2005. Cypermethrin and chlorpyrifos concentration levels in surface water bodies of the Pampa Ondulada, Argentina. Bull Environ Contam Toxicol 75:820-826.

8. Cámara de Sanidad Agropecuaria y Fertilizantes. 2015. Guía de Productos Fitosanitarios 2013/2015. CASAFE, Buenos Aires, Argentina.

9. Denton D, Wheelock C, Murray S, Deanovic L, Hammock B, Hinton D 2003. Joint acute toxicity of esfenvalerate and diazinon to larval fathead minnows (Pimephales promelas). Environ Toxicol Chem 22:336-341.

10. Wacksman MN, Maul JD, Lydy MJ. 2006. Impact of atrazine on chlorpyrifos toxicity in four aquatic vertebrates. Arch Environ Contam Toxicol 51:681-689.

11. Iannacone J, Alvariño L, Mamani N. 2011. Estimación de la Toxicidad Combinada de Mezclas de Furadán $4 \mathrm{~F}^{\circledR}$ y Monofos $^{\circledR}$ sobre Oncorhynchus mykiss (Walbaum, 1792). J Braz Soc Ecotoxicol 6: 23-29.

12. Brodeur JC, Poliserpi MB, D’Andrea MF, Sanchez M. 2014. Synergy between glyphosate- and cypermethrin-based pesticides during acute exposures in tadpoles of the common South American toad Rhinella arenarum. Chemosphere 112:70-76.

13. Shinn C, Santos MM, Lek S, Grenouillet G. 2015. Behavioral response of juvenile rainbow trout exposed to an herbicide mixture. Ecotox Environ Safe 112:15-21.

14. van der Oost R, Beyer J, Vermeulen NPE. 2003. Fish bioaccumulation and biomarkers in environmental risk assessment: A review. Environ Toxicol Pharm 13:57-149.

15. Vighi M, Di Guardo A. 1995. Predictive approaches for the evaluation of pesticide exposure. In Vighi M, Funari E eds, Pesticide Risk in Groundwater. CRC, Boca Raton, FL, USA, pp 73-85.

16. Arnot JA, Gobas FAPC. 2003. A generic QSAR for assessing the bioaccumulation potential of organic chemicals in aquatic food webs. QSAR Comb Sci 22:337-345.

17. Muir DCG, Hobden BR, Servos MR. 1994. Bioconcentration of pyrethroid insecticides and DDT by rainbow trout: Uptake, depuration, and effect of dissolved organic carbon. Aquat Toxicol 29:223-240.

18. Laskowski DA. 2002. Physical and chemical properties of pyrethroids. Rev Environ Contam Toxicol 174:49-170.

19. El-Amrani S, Pena-Abaurrea M, Sanz-Landaluze J, Ramos L, Guinea J, Camara C. 2012. Bioconcentration of pesticides in zebrafish eleutheroembryos (Danio rerio). Sci Total Environ 425:184-190.

20. Tsuda T, Kojima M, Harada H, Nakajima A, Aoki S. 1997. Relationships of bioconcentration factors of organophosphate pesticides among species of fish. Comp Biochem Phys C 116:213-218.

21. Hayes RK. 2010. Handbook of Pesticide Toxicology. AcademicElsevier, Philadelphia, PA, USA.

22. Tutundjian R, Cachot J, Leboulenger F, Minier C. 2002. Genetic and immunological characterisation of a multixenobiotic resistance system in the turbot (Scophthalmus maximus). Comp Biochem Phys B $132: 463-471$
23. Edwards R, Millburn P. 1987. The toxicity and metabolism of the pyrethroids cis and trans-cypermethrin in rainbow trout, Salmo gairdneri. Xenobiotica 17:1175-1193.

24. Carriquiriborde P, Marino DJ, Giachero G, Castro EA, Ronco AE. 2012. Global metabolic response in the bile of pejerrey (Odontesthes bonariensis, Pisces) sublethally exposed to the pyrethroid cypermethrin. Ecotox Environ Safe 76:46-54.

25. Barron MG, Plakas SM, Wilga PC, Ball T. 1993. Absorption, tissue distribution and metabolism of chlorpyrifos in channel catfish following waterborne exposure. Environ Toxicol Chem 12:1469-1476.

26. Wang X, Xing H, Jiang Y, Wu H, Sun G, Xu Q, Xu S. 2013. Accumulation, histopathological effects and response of biochemical markers in the spleens and head kidneys of common carp exposed to atrazine and chlorpyrifos. Food Chem Toxicol 62:148-158.

27. Venkateswara Rao J, Begum G, Pallela R, Usman PK, Nageswara Rao R. 2005. Changes in behavior and brain acetylcholinesterase activity in mosquito fish, Gambusia affinis in response to the sub-lethal exposure to chlorpyrifos. Int J Environ Res Public Health 2:478-483.

28. Xing H, Wang X, Sun G, Gao X, Xu S. 2012. Effects of atrazine and chlorpyrifos on activity and transcription of glutathione S-transferase in common carp (Cyprinus carpio L.). Environ Toxicol Pharm 33:233-244.

29. Xing H, Zhang Z, Yao H, Liu T, Wang L, Xu S, Li S. 2014. Effects of atrazine and chlorpyrifos on cytochrome P450 in common carp liver. Chemosphere 104:244-250.

30. Kullander SO. 1998. A phylogeny and classification of the neotropical Cichlidae (Teleostei: Perciformes). In Malabarba LR, Reis RE, Vari RP, Lucena ZMS, Lucena CAS, eds, Phylogeny and Classification of Neotropical Fishes, EDIPUCRS, Porto Alegre, Brazil, pp 461-498.

31. Bonansea RI, Wunderlin DA, Amé MV. 2016. Behavioral swimming effects and acetylcholinesterase activity changes in Jenynsia multidentata exposed to chlorpyrifos and cypermethrin individually and in mixtures. Ecotox Environ Safe 129:311-319.

32. Bistoni MA, Hued AC. 2002. Patterns of fish species richness in rivers of the central region of Argentina. Braz J Biol 62:753-764.

33. Polat H, Erkoc FU, Viran R, Kocak O. 2002. Investigation of acute toxicity of beta-cypermethrin on guppies Poecilia reticulata. Chemosphere 49:39-44.

34. Sharbidre AA, Metkari V, Patode P. 2011. Effect of methyl parathion and chlorpyrifos on certain biomarkers in various tissues of guppy fish, Poecilia reticulata. Pestic Biochem Phys 101:132-141.

35. Best JH, Pflugmacher S, Wiegand C, Eddy FB, Metcalf JS, Codd GA. 2002. Effects of enteric bacterial and cyanobacterial lipopolysaccharides, and of microcystin-LR, on glutathione S-transferase activities in zebra fish (Danio rerio). Aquat Toxicol 60:223-231.

36. European Commission. 2010. Guidance document on method validation and quality control procedures for pesticide residues analysis in food and feed. SANCO/10648/2009. Brussels, Belgium.

37. Monferrán MV, Galanti LN, Bonansea RI, Ame MV, Wunderlin DA 2011. Integrated survey of water pollution in the Suquia River basin (Cordoba, Argentina). J Environ Monitor 13:398-409.

38. Habig WH, Pabst MJ, Jakoby WB. 1974. Glutathione S-transferases. The first step in mercapturic acid formation. J Biol Chem 249:71307139.

39. Bradford MM. 1976. A rapid and sensitive method for the quantification of microgram quantities of proteins utilizing the principle of protein-dye binding. Anal Biochem 72:248-254.

40. Chomczynski P, Sacchi N. 1987. Single-step method of RNA isolation by acid guanidinium thiocyanate-phenol-chloroform extraction. Anal Biochem 162:156-159.

41. Amé MV, Baroni MV, Galanti LN, Bocco JL, Wunderlin DA. 2009. Effects of microcystin-LR on the expression of P-glycoprotein in Jenynsia multidentata. Chemosphere 74:1179-1186.

42. Amé MV, Galanti LN, Wunderlin DA. 2008. Evaluación de la expresión de Citocromo P450 1A y P-glicoproteína por real time RTPCR en distintos órganos de Jenynsia multidentata expuesta a lindano. II Congreso Argentino de la Sociedad de Toxicología y Química Ambiental (SETAC), Mar del Plata, Argentina, 26-28 November 2008.

43. Klaassen CD. 2008. Casarett and Doull's Toxicology: The Basic Science of Poisons. McGraw-Hill, New York, NY, USA.

44. Bevelhimer MS, Beauchamp JJ, Sample BE, Southworth GR. 1997. Estimation of whole fish contaminant concentrations from fish fillet data. Environmental Restoration Program. ES/ER/TM-202. US Department of Energy, Washington, DC. 1-16.

45. Di Rienzo JA, Casanoves F, Balzarini MG, Gonzalez L, Tablada M, Robledo CW. 2011. InfoStat versión 2011. Grupo InfoStat, FCA, Universidad Nacional de Córdoba, Argentina. 
46. Scollon EJ, Starr JM, Godin SJ, DeVito MJ, Hughes MF. 2009. In vitro metabolism of pyrethroid pesticides by rat and human hepatic microsomes and cytochrome p450 isoforms. Drug Metab Dispos 37:221-228.

47. Stacke Ferreira R, Monserrat JM, Ribas Ferreira JL, Kalb AC, Stegeman J, Dias Bainy AC, Zanette J. 2012. Biomarkers of organic contamination in the South American fish Poecilia vivipara and Jenynsia multidentata. J Toxicol Environ Heal 75:16-17.

48. Amé MV, Galanti LN, Menone ML, Gerpe MS, Moreno VJ, Wunderlin DA. 2010. Microcystin-LR,-RR,-YR and-LA in water samples and fishes from a shallow lake in Argentina. Harmful Algae 9:66-73.

49. Crawford MJ, Croucher A, Hutson DH, Sag KME. 1981. The metabolism of the pyrethroid insecticide cypermethrin in rats; Excreted metabolites. Pestic Sci 12:399-411.

50. Egaas E, Sandvik M, Fjeld E, Kallqvist T, Goksoyr A, Svensen A. 1999. Some effects of the fungicide propiconazole on cytochrome P450 and glutathione S-transferase in brown trout (Salmo trutta). Comp Biochem Phys 122:337-344.

51. Sharma P, Firdous S, Singh R. 2014. Neurotoxic effect of cypermethrin and protective role of resveratrol in Wistar rats. Int J Nutr Pharm Neurol Dis 4:104-111.

52. Cazenave J, Bistoni Mde L, Pesce SF, Wunderlin DA. 2006. Differential detoxification and antioxidant response in diverse organs of Corydoras paleatus experimentally exposed to microcystin-RR. Aquat Toxicol 76:1-12.

53. Bruggeman WA, Opperhuizen A, Wijbenga A, Hutzinger O. 1984. Bioaccumulation of super-lipophilic chemicals in fish. Toxicol Environ Chem 7:173-189.

54. Welling W, de Vries JW. 1992. Bioconcentration kinetics of the organophosphorus insecticide chlorpyrifos in guppies (Poecilia reticulata). Ecotox Environ Safe 23:64-75.

55. Ballesteros ML, Gonzalez M, Wunderlin DA, Bistoni MA, Miglioranza KS. 2011. Uptake, tissue distribution and metabolism of the insecticide endosulfan in Jenynsia multidentata (Anablepidae, Cyprinodontiformes). Environ Pollut 159:1709-1714.
56. Tang J, Cao Y, Rose RL, Brimfield AA, Dai D, Goldstein JA, Hodgson E. 2001. Metabolism of chlorpyrifos by human cytochrome P450 isoforms and human, mouse, and rat liver microsomes. Drug Metab Dispos 29:1201-1204.

57. Wheelock CE, Eder KJ, Werner I, Huang H, Jones PD, Brammell BF, Elskus AA, Hammock BD. 2005. Individual variability in esterase activity and CYP1A levels in Chinook salmon (Oncorhynchus tshawytscha) exposed to esfenvalerate and chlorpyrifos. Aquat Toxicol 74:172-192.

58. Lanning CL, Fine RL, Corcoran JJ, Ayad HA, Rose RL, Abou-Donia MB. 1996. Tobacco budworm P-glycoprotein: Biochemical characterization and its involvement in pesticide resistance. Biochim Biophys Acta 1291:155-162.

59. David M, Marigoudar SR, Patil VK, Halappa R. 2012. Behavioral, morphological deformities and biomarkers of oxidative damage as indicators of sublethal cypermethrin intoxication on the tadpoles of $D$. melanostictus (Schneider, 1799). Pestic Biochem Phys 103:127-134.

60. Tang J, Cao Y, Rose RL, Hodgson E. 2002. In vitro metabolism of carbaryl by human cytochrome $\mathrm{P} 450$ and its inhibition by chlorpyrifos. Chem Biol Interact 141:229-241.

61. Food and Agricultural Organization of the United Nations/World Health Organization. 2004. Residues of some veterinary drugs in animals and foods. Sixty-second Meeting of the Joint FAO/WHO Expert Committee on Food Additives, Rome, Italy, pp 4-12.

62. Food and Agricultural Organization of the United Nations/World Health Organization. 2004. Pesticide residues in food. Report of the Joint Meeting of the FAO Panel of Experts on Pesticide Residues in Food and the Environment, and the WHO Core Assessment Group on Pesticide Residues, Rome, Italy, pp 20-29.

63. Bicker W, Lämmerhofer M, Genser D, Kiss H, Lindner W. 2005. A case study of acute human chlorpyrifos poisoning: Novel aspects on metabolism and toxicokinetics derived from liquid chromatography-tandem mass spectrometry analysis of urine samples. Toxicol Lett 159:235-251.

64. Barron MG, Plakas SM, Wilga PC. 1991. Chlorpyrifos pharmacokinetics and metabolism following intravascular and dietary administration in channel catfish. Toxicol Appl Pharm 108:474-482. 